\title{
Pidana Pelatihan Kerja Pengganti Denda yang Berkemanfaatan dalam Perspektif Perlindungan Anak
}

\author{
NuriniAprilianda \\ FakultasHukumUniversitasBrawijaya \\ aprilianda@yahoo.co.id / nurini.aprilianda@ub.ac.id
}

Submit: 16-03-2020; Review: 06-05-2020; Terbit: 17-06-2020

\begin{abstract}
This research is aimed to find out, understand, and analyse ratio legis of regulation concerning job training as mentioned in Law concerning Juvenile Court System. Statute approaches were employed in this research, supported by legal materials that were analysed and interpreted based on systematic, grammatical, and teleological interpretation technique.

The research result shows the following: (1) the ratio legis of job training mentioned in UU SPPA is that the sanction should be given based on the levels of punishment severity, where the sanction should be delivered based on the structure of punishment in UU SPPA as follows: warning; conditional punishment; job training; training delivered in the Department of Corrections; and imprisonment. Jail sentence is positioned in the last structure to make it the least option taken by the judge in terms of delivering sanction to $A B H$ due to consideration that it may negatively affect the child's future. (2) Sanction where job training is implemented for the child concerned regulated as primary criminal sanction in UU SPPA is deemed irrelevant, recalling that there is no element of disapprobation. In terms of the regulation for job training as in UU SPPA and Law concerning Labour Affairs, the job training is more considered as a sanction aimed to discipline the child.
\end{abstract}

Keywords: Child, Job Training as Punishment, Criminal.

\begin{abstract}
Abstrak
Tulisan merupakan hasil penelitian yang bertujuan untuk menggali dan menganalisis ratio legis pembentuk undang-undang menetapkan pidana pelatihan kerja sebagai pengganti denda bagi anak. Untuk menjawab tujuan tersebut, digunakan metode penelitian normatif, dengan pendekatan peraturan perundangundangan dan dianalisis berdasarkan metode penafsiran sistematis, gramatikal dan intrepetasi teleologis.

Hasil penelitian menunjukkan bahwa ratio legis penetapan pidana pelatihan kerja sebagai pengganti denda dalamUndang-undang No. 11 Tahun 2012 Tentang Sistem Peradilan Pidana Anak adalah sebagai berikut: (1) pidana denda tidak dikenakan pada anak-anak di bawah umur, karena asumsinya mereka belum bekerja. Bila denda dijatuhkan pasti yang akan membayar adalah orang tuanya. Oleh sebab itu, tidak ada pidana denda di dalam Undang-Undang ini. (2) diharapkan agar lebih baik anak sendiri bertanggung jawab terhadap perbuatan yang dilakukannya. Oleh karena itu, mungkin karena anak tidak bias bekerja atau
\end{abstract}


tidak punya uang, harus dicari alternatif lain supaya anak merasa dia bertanggung jawab terhadap perbuatannya yaitu pelatihan kerja.

\section{Kata Kunci: Anak, Pidana Pelatihan Kerja, Pidana.}

\section{Pendahuluan}

Negara Indonesia masih
memiliki angka yang cukup
signifikan dari segi permasalahan
hukum yang melibatkan anak.
Persoalan pada anak dewasa ini
dianggap cukup beragam. Anak
Berhadapan Hukum atau biasa
disebut dengan ABH pada tahun
semester pertama 2018 terdapat

1.885 kasusanak yang mana ada 504 kasus ABH. Sepanjang tahun 20112017 terdapat 9.266 kasus. Pertahun, jumlah paling banyak terjadi pada tahun 2014 dimana kasus anak mencapai jumlah 2.208. Urutan yang kedua ada di tahun 2013 dengan jumlah kasu ssebanyak 1.428 dan yang terakhir pada tahun 2012 dengan jumlah 1.413 kasus (http://www.kpai.go.id/berita/kpaikurun-waktu-6-tahun-abh-sudahmencapai-9-266-kasus).

Komisi Perlindungan Anak Indonesia (KPAI) menyatakan Kasus Pengaduan yang masuk di KPPAI, tahun 2015 berjumlah 4.309 kasus, tahun 2016 mencapai 4.622 kasus, selanjutnya tahun 2017 berjumlah 4.579 kasus dan tahun 2018 mencapai 4.885 kasus. Di tahun 2018 kasus Anak Berhadapan Hukum masih menduduki urutan pertama yaitu mencapai 1.434 kasus. Kasus $\mathrm{ABH}$ didominasi kasus kekerasan seksual yang mana laki-laki mendominasi sebagai pelaku dibandingkan dengan anak pe rempuan. Sepanjang tahun 2018, pelaku berjumlah 103, sedangkan pelaku berjenis kelamin perempuan berjumlah 58 anak http://www.kpai.go.id/berita/kpaisebut-pelanggaran-hak-anak-terusmeningkat ).

Data Permasyarakatan untuk di daerah Jawa Timur pada akhir tahun 2015 jumlah nara pidana anak sebanyak 2.017 anak. Kemudian akhir tahun 2016 jumlahnya meningkat sebanyak 2.123 anak. Sedangkan di bulan Juni tahun 2017 jumlah narapidana anak sebanyak 3.983. ( http://smslap.ditjenpas.go.id) 
Di antara narapidana anak yang menjalani pidana penjara tersebut, terdapat narapidana anak yang selain dijatuhi pidana penjara juga dijatuhi pidana pelatihan kerja sebagai penggan tidenda. Hal ini dijatuhkan hakim sesuai dengan ketentuan pasal 71 (3) Undang-UndangNomor 11 tahun 2012 tentang Sistem Peradilan Pidana Anak (UU SPPA) bahwa : Apabila dalam hukum materiil diancam pidana kumulatif berupa penjara dan denda, pidana denda diganti dengan pelatihan kerja.

Beberapa narapidana anak yang dijatuhi pidana penjara dan pidana pelatihan kerja pengganti denda dapat dilihat dalam beberapa putusan sebagaiberikut.

1)

Putusan PN

Kabupaten Kediri Nomor : 23/Pid.Sus/An/2015/PN.Gpr.Hak im Anak menjatuhkan pidana penjara selama 2 (dua) tahun 8 (delapan) bulan dan pelatihan kerja selama 6 (enam) bulan terhadap DP (14 tahun), karena terbukti melakukan tindak pidana pencabulan sebagaimana diatur dalam Pasal 82 (1) jo Pasal 76 E UU RI No 35 tahun 2014 tentang perubahan atas UU RI No. 23 tahun 2002 tentang Perlindungan Anak.

2) Putusan PN Jombang Nomor 02/Pid.Sus-Anak/2016/PN.JBG, menyatakan mengadili Anak EP yang telah terbukti secara sah dan meyakinkan bersalah melakukan tindak pidana "Membujuk anak untuk melakukan persetubuhan dengannya terus menerus sebagai perbuatan yang dilanjutkan". Karenanya EP dijatuhi pidana penjara selama 1 (satu) tahun dan pelatihan kerja selama 3 (tiga) bulan di Lembaga Perlindungan dan Pendamping Anak (LP2A) Jombang. EP terbukti melakukan tindak pidana sebagaimana diatur dalam pasal 81 ayat (2) UU RI No 35 tahun 2014 tentang perubahan atas UU RI No. 23 tahun 2002 tentang PerlindunganAnak jo pasal 64 ayat (1) KUHP, UU RI No. 11 tahun 2012 tentang Sistem Peradilan Pidana Anak.

3) Putusan PN Kendal Nomor: 2/Pid.SUS.Anak/2016/PN.K.

Hakim anakdi PN Kendal menjatuhkan sanksi pidana 
penjara selama 2 tahun 6 bulan di LPKA KUTOARJO serta pelatihan kerja selama 3 bulan di Lembaga Pelatihan Kerja pada KU (12 tahun) karena melakukan tindak pidana pencabulan sebagaimana diatur dalam Pasal 82 ayat (1) UU No. 35 tahun 2014 Tentang Perubahan terhadap UU No. 23 Tahun 2002 Tentang Perlindungan anak

UU SPPA tidak memberikan pengertian dan penjelasan lebih lanjut mengenai pidana pelatihan kerja sebagai pengganti denda. Pelatihan kerja sendiri menurut Pasal 1 angka 9 UU 13 tahun 2003 tentang Ketenagakerjaan adalah keseluruhan kegiatan untuk memberi, memperoleh, meningkatkan, serta mengembangkan kompetensi kerja, produktivitas, disiplin, sikap, dan etos kerja pada tingkat keterampilan dan keahlian tertentu sesuai dengan jenjang dan kualifikasi jabatan atau pekerjaan. Lebih lanjut, dalam UU Ketenagakerjaan ditegaskan bahwa Pengusaha dilarang mempekerjakan anak (Pasal 68), kecuali bagi anak yang berumur antara 13 (tigabelas) tahun sampai dengan 15 (lima belas) tahun untuk melakukan pekerjaan ringan sepanjang tidak mengganggu perkembangan dan kesehatan fisik, mental, dan sosial (Pasal 69). Hal ini dapat dipahami karena sesuai dengan prinsip perlindungan anak, anak tidak boleh dieksploitasi. Namun demikian, tidak terdapat penjelasan apakah ketentuan dalamUU ketenagakerjaan dapat diberlakukan bagi Anak yang dijatuhi pidana pelatihan kerja pengganti denda.

Berdasarkan uraian di atas, tulisan ini membahas tentang: ratio legis pembentuk undang-undang menetapkan pidana pelatihan kerja sebagai pengganti denda bagi anak dan konsep pidana pelatihan kerja sebagai pengganti denda yang berkemanfaatan dalam perspektif perlindungan anak. Untuk menjawab 2 hal tersebut, digunakan penelitian hukum normatif dengan pendekatan perundang-undangan.

\section{Metode Penelitian}

Penelitian ini merupakan penelitian normatif yaitu penelitian yang beranjak dari isu yang ada dalam peraturan perundanganundang. Sebagai penelitian normatif 
maka pendekatan yang digunakan adalah perundang-undangan. Sumber bahan hukum berasal dari data sekunder berupa peraturan perundang-undangan yang relevan, teori dan pendapat para pakar. Analisis yang digunakan adalah analisis berdasarkan metode penafsiran sistematis, gramatikal dan intrepetasi teleologis.

\section{Hasil dan Pembahasan}

Ratio Legis Pembentuk UndangUndang Menetapkan Pidana Pelatihan Kerja Sebagai Pengganti Denda Bagi Anak

Perlindungan terhadap anak merupakan salah satu tanggung jawab Negara. Hal ini dijelaskan dalam Pasal 28B UUD Tahun 1945 bahwa setiap anak memperoleh hak untuk kelangsungan hidupnya, serta memperoleh perlindungan daritindakan diskriminasi. Oleh karena itu, penanganan bagi Anak yang berkonflik dengan hukum (selanjutnya $\mathrm{ABH}$ ) janganlah sampai menimbulkan stigmatisasi atau labeling dan kurangnya atau bahkan ketiadaan pembinaan terhadap mereka sehingga membuyarkan harapan-harapan mereka menjadi pemuda yang berguna bagi bangsanya (Djamil, 2013: 4) Mengacu pada hal tersebut penting untuk menyepakati model penanganan $\mathrm{ABH}$.

Sejak tanggal 3 Januari 1998 melalui Undang-Undang Nomor 3 Tahun 1997 terdapat unifikasi hokum melalui peradilan anak. Dalam undang-undang tersebut mengakomodasi mengenai teori dan praktek tentang peradilan anak yang sebelumnya sudah ada. Tetapi karena perkembangan zaman dan teknologi, undang-undang ini dirasakan sudah tidak relevan lag iuntuk diterapkan. Dengan pertimbangan: (Konsiderans UU 11/2012 tentang Sistem Peradilan Pidana Anak).

a) Bahwa anak adalah amanah dan juga karunia dari Tuhan Yang Maha Esa yang mempunyai harkat dan mertabat sebagai manusia seutuhnya.

b) Bahwa untuk melindungi harkat dan juga martabatnya, anak memiliki hak terhadap perlindungan khusus, terutama perlindungan hukum dan system peradilan. 
c) Bahwa Indonesia sebagai salah satu Negara yang ikut dalam Konvensi Hak-Hak Anak (Convention on the Rights of the Child), mengatur tentang prinsip perlindungan hokum bagi anak memiliki kewajiban untuk memberikan perlindungan khusus bagi anak yang berhadapan dengan hukum.

d) Bahwa dalam Undang-undang No. 3 Tahun 1997 tentang Pengadilan Anak (selanjutnya disebut dengan Undang-undang Pengadilan Anak) sudah tidak cocok lagi dengan kebutuhan dan perkembangan masyarakat dikarenakan belum dapat memberikan perlindungan kepada anak yang berhadapan dengan hokum secara menyeluruh sehingga perlu diganti dengan Undang-undang baru.

Berdasarkan pertimbangan tersebut, maka perlu dibentuk Undang-undang baru yang mengatur mengenai Anak, dan karena itu diberlakukan Undang-undang No. 11 Tahun 2012 tentang Sistem Peradilan Pidana Anak (selanjutya disebut UU
SPPA). UU SPPA ini membawa beberapa perubahan di antaranya ialah konsep diversi. Serta menggunakan model restorative justice, yakni model penyelesaian perkara yang mengutamakan pengembalian keadaan seperti semula, keadaan sebelum terjadinya sutau tindak pidana.

Anak harus ditangani secara berbeda dengan orang dewasa. Oleh sebab itu, secara paradigma model penanganan yang berlaku melalui Undang-undang Pengadilan Anak, adalah sama dengan orang dewasa, dengan model Retributive Justice, yakni pidana sebagai pilihan utama atau pembalasan atas tindak pidana yang telah dilakukan. Model ini sudah tidak sesuai, ketidaksesuainnya tersebut berdasarkan 3 (tiga) pertimbangan: pertama, alasan karakteristi kanak. Undang-Undang Perlindungan Anak (Undang-undang Nomor 23 Tahun 2002) menyebutkan untuk tumbuh dan berkembang secara optimal, baikfisik mental maupun sosial, dan berahlak mulia. Anak belum dapat menentukan pilihan tindakan secara benar, hal ini dikarena kananak 
merupakan individu yang masih harus tumbuh dan berkembang dalam segala aspek. Kedua, alasan masa depan anak. Anak yang dipidana terlabel dan terstigmatisasi selepas pemidanaan sehingga Menyulitkan pertumbuhan psikis dan sosial anak kedepan. Ketiga, memulihkan hubungan antara $\mathrm{ABH}$, korban dan masyarakat. (Undangundang Nomor 23 Tahun 2002 tentang Perlindungan Anak)

Hukuman yang diberikan kepada anak tidak berorientasi pada pembalasan, hukuman yang diberikan kepada anak wajib mempertimbangkan prinsip- prinsip perlindungan anak. Pidana pokok dalam UU SPPA diatur dalam Pasal 71:

(1)Pidana pokok bagi Anak terdiri atas:

a) pidana peringatan;

b) pidana dengan syarat: 1) pembinaan di luar lembaga; 2) pelayanan masyarakat; atau 3) pengawasan.

c) pelatihan kerja;

d) pembinaan dalam lembaga; dan e) penjara.

(2)Pidana tambahan terdiri atas:

a) perampasan keuntungan yang diperoleh dari tindak pidana; atau

b) pemenuhan kewajiban adat.

(3) Apabila dalam hukum materiil diancam pidana kumulatif berupa penjara dan denda, pidana denda diganti dengan pelatihan kerja.

(4)Pidana yang dijatuhkan kepada Pidana yang dijatuhkan kepada Anak dilarang melanggar harkat dan martabat Anak.

Salah satu bentuk pidana yang terdapat dalam pasal tersebut adalah pidana denda. Namun memberikan pidana denda kepada $\mathrm{ABH}$ tidaklah tepat mengingat $\mathrm{ABH}$ biasanya belum memiliki pekerjaan. Oleh karena itu dalam Pasal 71 ayat (3) UU SPPA menyebutkan apabila dalam hokum materiil diancam pidana kumulatif berupa penjara dan denda, pidana denda diganti dengan pelatihan kerja. Pidana pelatihan 
kerja dijadikan pidana pengganti terhadap penjatuhan pidana denda bagi $\mathrm{ABH}$. Namun apakah dengan menggantikan pidana denda dengan pidana pelatihan kerja dapat memberikan suatu perlindungan dan kemanfaatan bagi ABH. Apa yang menjadi dasar penggantian pidana denda kepidana pelatihan kerja.

Pidana pelatihan kerja sebagai pengganti pidana denda telah dikenal sejak diundangkannya UU No. 3 Tahun 1997 yang kemudian diganti dengan Undang-Undang Nomor 11 Tahun 2012 tentang Sistem Peradilan Pidana Anak. Dalam UU Pengadilan Anak menyatakan bahwa anak yang diberikan putusan subside wajib latihan kerja adalah mereka yang dijatuhi pidana kumulatif penjara dan denda. Demikian kemudian anak yang tidak membayar denda dan melaksanakan wajib latihan kerja. Sebagaimana tujuan system peradilan pidana anak untuk mewujudkan kesejahteraan anak sebagai landasan perlindungan hokum bagi anak yang bermasalah dengan hokum ini adalah memberikan keterampilan hinggaia dapat mandiri dan mempunyai kehidupan lebih baik setelah kembalinya menjadi bagian dari masyarakat (Anggraini, 2013:11).

Pasal 71 ayat (3) UU SPPA menyebutkan bahwa "apabila dalam hokum materiil diancam pidana kumulatif berupa penjara dan denda, pidana denda diganti dengan pelatihan kerja”. Digantinya pidana denda kepidana pelatihan kerja tentu memiliki alasan tersendiri. Untuk dapat mengetahui sebab dan alas an pidana denda bagi $\mathrm{ABH}$ diganti dengan pelatihan kerja, maka akan dipaparkan ratio legis dari Pasal 71 ayat (3) UU SPPA sebagai berikut:

1) Kalau usulan dari Gerinda ini memang pidana denda tidak dikenakan pada anak-anak di bawah umum, karena asumsinya merekakan belum bekerja. Jadi, kalau ada denda pasti yang bayarorangtuanya. Oleh sebab itu, tidak ada pidana denda di dalamUndang-Undang ini (Harkristuti dalam Risalah UU No. 11 Tahun 2012 tentang SPPA).

2) Pertanggungjawaban Orang Tua Di negara-negara lain orang tua bertanggung jawab, biasanya 
secara ekonomis, berarti untuk ganti rugi dan denda. Orang tua yang biasanya harus pertanggungjawaban, tetapi di banyak negara sebenarnya lebih baik anak sendiri bertanggungjawab. Oleh karena itu, mungkin karena anak tidak bias bekerja atau tidak punya uang, kita harus cari alternatif lain. Misalnya, apakah anak bias membantu selama beberapa bulan korban. Misalnya, jika korban adalah orang yang bekerja di took apakah anak bias tidak membantu korban. Berarti lebih baik daripada denda yang atau uang, sanksinya lain supaya anak merasa

dia bertanggungjawab dan dia yang harus merespon (Arosio Asnar dalam Risalah UU No. 11 Tahun 2012 tentang SPPA).

3) Pasal 79, pidana pelatihan kerja sebagaimana dimaksud dalam Pasal 72 Ayat (1) huruf c dilaksanakan di lembaga yang melaksanakan pelatihan kerja yang sesuai dengan usia anak. Tidak ada masalah saya pikir (Aziz Syamsudin, dalam Risalah
UU No. 11 Tahun 2012 tentang SPPA).

Dari risalah pembentukan Pasal 71 ayat (3) UU SPPA di atas dapat ditarik kesimpulan bahwa terdapat dua pendapat, pertama.bahwa pidana denda merupakan sanksi yang tidak tepat bagi $\mathrm{ABH}$, karena $\mathrm{ABH}$ belum memiliki penghasilan untuk membayar pidana denda tersebut. Kedua orang tua dapat bertanggung jawab atas perbuatan yang $\mathrm{ABH}$ lakukan, jadi orang tua yang membayar pidana denda yang dijatuhkan terhadap $\mathrm{ABH}$.

Seperti yang dikemukakan oleh Sudarto bahwa tujuan utama perlindungan hokum bagi anak adalah untuk mewujudkan kesejahteraan Anak disamping kepentingan masyarakat. Kepentingan Anak tidak boleh dikorbankan demi kepentingan masyarakat. Untuk hal tersebut, terdapat dua asas penting yang harus diperhatikan adalah;

1) Memajukan Kesejahteraan Anak (the promotion of the well being of the juvenile)

Hal ini merupakan focus utama system hokum dalam menangani 
Anak yang melakukan pelanggaran, khususnya dalam sistem hukum yang mengikuti model peradilan pidana, system hokum harus lebih menekankan atau mengutamakan kesejahteraan Anak. Ditegaskan pula bahwa prinsip ini berarti menolak prinsip penggunaan sanksi yang hanya bersifat pidana atau yang bersifat menghukum semata (the avoidance of merely punitive sanctions).

2) Prinsip Proposionalitas (the Principle of Proportionality).

Prinsip proposionalitas, yaitu prinsip yang merupakan alat untuk dapat mengekang penggunaan sanksi yang hanya bersifat menghukum dalam arti pembalasan (just desort). Walaupun penekanan ini ditujukan pada permasalahan kesejahteraan Anak, namun perlu dicatat pendapat Paul W. Tappan yang menyatakan bahwa peradilan Anak janganlah hanya berfungsi sebagai suatu pengadilan pidana dan tidak pula harus berfungsi semata-mata sebagai lembaga sosial (the juvenile court should not function merely as a criminal court for children, not should it function merely as a social agency) (Sudarto, 1981:140).

Sistem hukum yang menangani anak haruslah menekankan perlindungan kesejahteraan terhadap anak tersebut, bukan sebalikya. Pidana denda bagi ABH merupakan hal yang sangat tidak tepat. Bagaimana mungkin $\mathrm{ABH}$ bias membayar denda sedangkan ABH itu sendiri belum memiliki penghasilan sendiri. Tentu hal tersebut sangat merugikan $\mathrm{ABH}$. Maka solusi yang terbaik adalah dengan mengganti pidana denda dengan pidana pelatihan kerja. Namun dalam pidana pelatihan kerja, harus tetap memperhatikan prinsip-prinsip perlindungan terhadap anak.

Berdasarkan konvensi Hak Anak yang kemudian diadopsi dalam UU No. 23 Tahun 2002 Tentang Perlindungan Anak yang sekarang dirubah oleh UU No. 35 Tahun 2014, ada empat prinsip umum perlindungan Anak yang menjadi dasar bagi setiap Negara dalam menyelenggarakan perlindungan anak, yaitu:

1) Prinsip Non diskriminasi 
2) Prinsip Kepentingan Terbaik Bagi Anak (Best Interests of The Child.

3) Prinsip Hak Hidup, Kelangsungan Hidup, dan Perkembangan (The Right to life, Survival, and Development)

4) Prinsip Penghargaan Terhadap Pendapat Anak (Respect for the views of the Child)
Perspektif perlindungan anak adalah cara pandangan terhadap semua persoalan dengan menempatkan posisi anak sebagai yang pertama dan utama. Implementasi cara pandang demikian adalah ketika selalu menempatkan anak sebagai hal yang paling utama. Berikut gambar mengenai perlindungan anak.

Gambar : Perlindungan bagi anak.

KepentinganTerbaik bagi anak

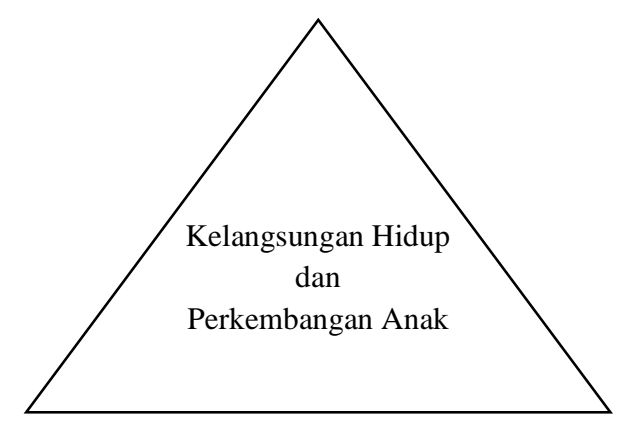

Nondiskriminasi

Partisipasi Anak (Djamil, 2013 :31).

(sumber: bahan hukum sekunder)

Membicarakan perlindungan perlindungan hukum yang sepatutnya hokum bagi anak dalam proses diberikan kepada anak. (Muladi dan peradilan tidak dapat dilepaskan dari Barda, 2010:119).

apa sebenarnya tujuan atau dasar

Pidana pelatihan kerja sebagai pemikiran dari peradilan anak itu pengganti pidana denda sebagaiman sendiri. Bertolak dari tujuan dan diatur dalamPasal 71 ayat (3) UU dasar pemikiran inilah baru dapat SPPA, harus memperhatikan empat ditentukan apa dan bagaimana prinsip perlindungan anak. Pidana hakikat serta wujud dari pelatihan kerja juga harus 
mempertimbangkan pendapat anak terhadap pekerjaan yang dilakukan oleh ABH. Pidana pelatihan kerja yang diberikan harus mendengar pendapat $\mathrm{ABH}$ dan mempertimbangkat bakat minat dari $\mathrm{ABH}$ itu sendiri.

Seperti yang terjadi di Lembaga Pembinaan Khusus Anak Kelas II B Pontianak. Dalam proses serah terima dari Lembaga Pembinaan Khusus Anak Kelas II B Pontianak kepada Dinas Sosial Kalimantan Barat, tidak ada pembahasan mengenai bakat, perkembangan jiwa dan bagaimana anak harus melaksanakan pidana subside latihan kerja (Anggraini, 2016 :20). Hasil wawancara dengan Kepala Bidang Pelayanan dan Rehabilitasi Sosial (PRS) Dinas Sosial Kalimantan Barat sebagai berikut : (Anggraini, 2016:20).

1) Tidak adanya dana untuk melaksanakan pidana subside latihan kerja secara mandiri, anak dititipkan di "Bengkel Las Intan" bagi yang berjenis kelamin lakilaki dan "Erna Swiss Salon" bagi perempuan, keduanya terletak di Jl. Suwignyokota Pontianak.
Karena semua berjenis kelamin laki-laki maka pelaksanaan pidana subsider latihan kerja di Bengkel Las Intan sebagai badan usaha pengelasan teralis.

2) Tidak ada kualifikasi untuk menentukan tempat pelaksanaan latihan kerja, hanya didasarkan pada hubungan baik.

3) Tidak ada perjanjian tertulis yang menyatakan keberalihan tanggungjawab atas anak yang melaksanakan pidana subside latihan kerja.

4) Dalam menitipkan anak melaksanakan pidana subside latihan kerja, Dinas Sosial Kalimantan Barat memberitahukan lama latihan kerja oleh anak dan batasan sebagaimana dimaksud dalam Pasal 28 ayat (3) UU No. 3 Tahun 1997 tentang Pengadilan Anak lama latihan kerjahanya 4 (empat) jam sehari serta tidak dilakukan pada malam hari.

5) Tidak ada pengawasan intensif dari DinasS osial Kalimantan Barat dalam pelaksanaan latihan kerja atapun bentuk absensi lainnya. 
6) Tidak ada evaluasi atas pelaksanaaan pidana subside latihan kerja.

7) Dinas Sosial melaporkan kepada Lembaga Pembinaan Khusus Anak Kelas II B Pontianak bahwa anak telah melaksanakan pidana subside latihan kerja dalam bentuk berita acara serah terima.

Pidana pelatihan kerja Lembaga Pembinaan Khusus Anak Kelas II B yang bekerja sama dengan Dinas Sosial Kalimantan Barat adalah salah satu contoh pidana pelatihan kerja yang kurang memperhatikan pendapat anak. Tentu hal ini bertentang dengan prinsip perlindungan anak yakni penghargaan terhadap pendapat anak. Namun terdapat kendala di lapangan yang membuat Lembaga Pembinaan Khusus Anak Kelas II B yang bekerjasama dengan Dinas Sosial Kalimantan Barat melakukan pidana pelatihan kerja terhadap $\mathrm{ABH}$, yakni kendala lokasi atau tempat anak menjalani pidana pelatihan kerja.

\section{Simpulan}

1) Ratio Legis Penetapan Pidana Pelatihan Kerja Sebagai Pengganti Denda DalamUndangUndang No. 11 Tahun 2012 Tentang Sistem Peradilan Pidana Anak adalah sebagai berikut:

a) Pidana denda tidak dikenakan pada anak-anak di bawah umur, karena asumsinya mereka belum bekerja. Bila denda dijatuhkan pasti yang akan membayar adalah orang tuanya. Oleh sebab itu, tidak ada pidana denda di dalamUndang-Undang ini.

b) $\mathrm{Di}$ beberapa Negara, pertanggungjawaban Orang Tua terhadap anaknya yang melakukan tindak pidana bersifat ekonomi dalam bentuk pemberian ganti kerugian kepada korban. Namun dibanyak negara disarankan agar lebih baik anak sendiri bertanggungjawab. Oleh karena itu, mungkin karena anak tidak bias bekerja atau tidak punya uang, kita harus cari alternatif lain supaya anak merasa dia bertanggungjawab terhadap perbuatannya. 


\section{Daftar Pustaka}

\section{Buku}

M. Nasir Djamil, Anak Bukan Untuk Dihukum, Catatan Pembahasan UU Sistem Peradilan Pidana Anak (UU-SPPA), Sinar Grafika, Jakarta, 2013.

Muladi dan Barda Nawawi Arif, Bunga Rampai Hukum Pidana, Alumni, Bandung, 2010.

Sudarto, Kapita Selekta Hukum Pidana, Alumni, Bandung, 1981.

\section{Jurnal}

Lina Anggraini, Wajib Latihan Kerja Sebagai Hukuman Alternatif dalam Sistem Peradilan Pidana Anak (Studi Kasus Pada Lembaga Pembinaan Khusus Anak Pontianak),Jurnal Nestor, Vol. 3, No. 3, 2016.

\section{Peraturan Perundang-undangan}

Undang- undang No. 4 Tahun 1979 tentang Kesejahteraan Anak

$$
\begin{gathered}
\text { Undang-undang Nomor } \begin{array}{r}
\text { 13tahun } \\
\text { tentang }
\end{array} \\
\text { Ketenagakerjaan }
\end{gathered}
$$

Undang-undang Nomor 23 tahun 2002 tentang Perlindungan Anak

Undang-undang Nomor 11 Tahun 2012 tentang Sistem Peradilan Pidana Anak
Undang- undang Nomor 23 Tahun 2002 tentang Perlindungan Anak

Undang-undangRepublik Indonesia Nomor 35 Tahun 2014 tentang Perubahan Atas Undang-undangNomor 23 tahun 2002 tentang Perlindungan Anak Peraturan Pemerintah Pengganti Undang- undang Republik Indonesia Nomor 1 Tahun 2016 tentang Perubahan Kedua atas Undang- undangNomor 23 Tahun 2002 tentang Perlindungan Anak

Pemerintah/Dirjen Ham (Harkristuti Harkrisnowo): Risalah UUNo. 11 Tahun 2012 tentang Sistem Peradilan Pidana Anak.

Juru Bicara Unicef (AROSIO ASNAR), Risalah UU No. 11 Tahun 2012 tentang Sistem Peradilan Pidana Anak.

Ketua Rapat (H. Aziz Syamsuddin, , Risalah UU No. 11 Tahun 2012 tentang Sistem Peradilan Pidana Anak.

Putusan PN Kabupaten Kediri Nomor : 23/Pid.Sus/An/2015/PN.Gpr

Putusan PN Jombang Nomor 02 / Pid . Sus-Anak / 2016 / PN. JBG 
Putusan PN Kendal Nomor: 2 /

Pid.SUS.Anak/2016/PN.K

\section{Internet}

http://www.kpai.go.id/berita/kpai-

kurun-waktu-6-tahun-abh-

sudah-mencapai-9-266-

kasus diakses pada tanggal

15 Februari 2020, pukul

20.30 .

http://www.kpai.go.id/berita/kpai-

sebut-pelanggaran-hak-

anak-terus-meningkat

http://smslap.ditjenpas.go.id

diakses pada tanggal 15 Februari

2020, pukul 20.39. 